\title{
Effects of Exhaust Backpressure Increment on the Performance and Exhaust Emissions of a Single Cylinder Diesel Engine
}

\author{
(ㄴ) Yiğit Gülmez ${ }^{1,2}$, @ Güner Özmen³ \\ ${ }^{1}$ Dokuz Eylül University, Graduate School of Natural and Applied Sciences, Department of Marine Transportation Systems \\ Engineering, İzmir, Turkey \\ ${ }^{2}$ İskenderun Technical University, Barbaros Hayrettin Naval Architecture and Maritime Faculty, Hatay, Turkey \\ ${ }^{3}$ Dokuz Eylül University, Maritime Faculty, Department of Marine Engineering, İzmir, Turkey
}

\begin{abstract}
Exhaust gas aftertreatment systems and exhaust gas waste heat recovery systems are main solutions to decrease the environmental impact and increase the efficiency of diesel engines. However, any system installed on the exhaust pipe of diesel engines is a source of exhaust backpressure. Moreover, increasing the exhaust backpressure has negative effects on the performance and environmental impact of diesel engines. The study aims to investigate the negative impacts of exhaust backpressure increment on performance indicators, fuel consumption and exhaust emissions of a diesel engine. The experimental study was performed on a test bench comprising a single cylinder diesel engine, a dynamometer and various measurement equipment. The backpressure was increased by adding various sized orifices on the exhaust pipe of the test engine and the test engine was run under six different engine loads at an engine speed of 1600 rpm. Subsequently, the impacts of backpressure increment on the brake specific fuel consumption (BSFC), brake thermal efficiency, volumetric efficiency, mean effective pressures, mechanical efficiency, and exhaust emissions were determined. The study results showed that backpressure increment causes retarding of combustion phases up to a crank angle of $4^{\circ}$, decrease in the indicated mean effective pressure, and decrease in the peak cylinder pressure from 78.36 to 70.7 bar at the maximum available engine load. From fuel consumption perspective, backpressure increment caused an increase in the BSFC approximately up to $3.29 \%$ at $24.66 \mathrm{kPa}$ backpressure. On the other hand, the results showed that increasing the backpressure caused a significant increment in the pumping mean effective pressure and a remarkable decrease in the volumetric efficiency. The findings of this study have significant implications for evaluating the negative impacts of any system installed on the exhaust pipe of a diesel engine.
\end{abstract}

\section{Keywords}

Exhaust backpressure, Cylinder pressure, Engine performance parameters, Exhaust emissions, Four-stroke diesel engine

\section{Introduction}

Diesel engines are the most widespread option for transportation of goods owing to their low operational and maintenance costs, high energy efficiency, and durability. However, the environmental impact of diesel engines and legal requirements to protect the environment from the negative impacts of engines have forced engine manufacturers to develop more environmental-friendly engines. Legal requirements to avoid air pollution requires to reduce the brake specific exhaust emissions, i.e., the quantity of pollutants emitted per unit of energy output.
There are a few methods to decrease the brake specific exhaust emissions caused by diesel engines. Some of the methods such as using a type of exhaust gas after treatment systems and exhaust heat regeneration systems require to install an additional system on exhaust pipe of the engine. However, any system installed on the exhaust pipe of an internal combustion engines largely results an increase in the exhaust backpressure due to increasing the resistance against the flow of exhaust gas.

The negative impact of backpressure due to the characteristics of any system installed on exhaust pipes for
Address for Correspondence: Yiğit Gülmez, Dokuz Eylül University, Graduate School of Natural and Applied Sciences, Department of Marine Transportation Systems Engineering, İzmir, Turkey

E-mail: yigit.gulmez@iste.edu.tr

ORCID ID: orcid.org/0000-0003-1955-6706
Received: 07.05 .2021 Accepted: 30.06 .2021

To cite this article: Y. Gülmez and G. Özmen, "Effects of Exhaust Backpressure Increment on the Performance and Exhaust Emissions of a Single Cylinder Diesel Engine." Journal of ETA Maritime Science, vol. 9(3), pp. 177-191, 2021.

${ }^{\circ}$ Copyright 2021 by the Journal of ETA Maritime Science published by UCTEA Chamber of Marine Engineers 
any purpose has been extensively discussed. In response to strict regulations to decrease the amount of harmful emissions in flue gas, as solution, there are a number of aftertreatment systems that can be installed on the exhaust outlet of diesel engines. As an effective $\mathrm{NO}_{x}$ reducing aftertreatment solution [1], selective catalytic reduction (SCR) systems have negative impacts on the performance of diesel engines due to increasing exhaust backpressure. A few studies have investigated the negative impact of SCR systems on backpressure. For instance, Zhang et al. [2] designed a new mixer for an SCR system to decrease the negative impact on engine performance. In the study, the exhaust backpressure was investigated as a performance indicator of the engine. The study has important results for the interaction between backpressure and SCR mixer design. However, the study did not investigate the effect of backpressure on combustion performance and exhaust emissions.

Diesel particulate filters (DPFs) are yet another aftertreatment system installed on diesel engines. These systems help filtrate the particles in the flue gas. However, the exhaust backpressure increases as the particles are captured within its matrix [3]. Backpressure increment of diesel engines is the main factor affecting the sizing of DPF systems in real world applications [4]. Several studies have described the effects of the type, design, and material selection of DPF systems on backpressure increment in internal combustion engines. Li et al. [5] compared diesel oxidation catalyst +DPF and electric diesel particulate trap systems considering the effects of both systems on exhaust backpressure and particulate trapping efficiency. In another study [6], the interactions between DPF and particulate oxidation catalyst were investigated in terms of the filtration and backpressure. D'Aniello et al. [7] developed a 0D model to investigate the aspect of the system with adding a catalytic silicon carbide wall flow DPF on the exhaust pipe of a diesel engine. In the study, the exhaust backpressure was considered as one of the characteristics of the system. These studies [5-7] have made contributions toward understanding the effects of DPF system characteristics on backpressure increments. However, these papers did not report any result on the negative impacts of backpressure on engine performance, fuel consumption, or brake specific exhaust emissions.

A DPF can accumulate a large volume of particle matters (PM) which causes high-pressure drop in the filter [8] and high backpressure increment in exhaust pipe. Investigating the impact of increasing PM accumulation on the performance of a diesel engine is a crucial point for researchers. Chiavola et al. [9] studied the loading process of a DPF filter considering to limit exhaust backpressure increment. In another study
[10], the effects of residual ash in a DPF on trapping performance of the filter and backpressure increment in exhaust line of the diesel engine have been investigated. Although increased ash accumulation is known to cause an increase in the backpressure $[9,10]$, there has been no study on the effect of increasing backpressure on diesel engine performance. Zhang et al. [11] conducted a study to estimate the impact of ash accumulation on DPF-related fuel penalty. Similarly, Wang et al. [12] investigated the effects of ash inside a platinum-based catalyst DPF on regulated and unregulated exhaust emissions of a diesel engine. The results of the studies [11,12] are important to analyze the effect of backpressure increment on exhaust emissions.

Waste heat recovery (WHR) systems enable to produce energy by utilizing the waste heat of the engine. However, adding any type of WHR system on the exhaust outlet of an engine is a source of exhaust backpressure. Any loss in engine brake power due to backpressure increment may even decrease the total efficiency of the system. Extensive studies have investigated the effect of increasing backpressure on the system efficiency. Wu et al. [13] made a model design to maximize the Organic Rankine Cycle (ORC) system energy output by considering to limit the negative impact of the system to vehicle performance. Similarly, Baldasso et al. [14] proposed a model for the optimal design of an ORC system mounted on exhaust line of a marine engine by considering the effect of increased backpressure on the performance of both engine and ORC. The results of the studies $[13,14]$ considered the brake specific fuel consumption (BSFC) of complete system including the test engine and ORC system, and thus, the power output included the power generated by the ORC system. Zhao et al. [15] investigated the effect of ORC system operating conditions on the performance of the diesel engine. Similarly, in another study [16], the negative impact of an exhaust ORC system on diesel engine fuel economy for off-highway vehicles was investigated. The study evaluated positive and negative impacts of increasing backpressure, increasing heat exchanger weight and the effects of all variables on fuel consumption of the engine and power regeneration of the ORC system. Di Battista et al. [17] developed a mathematical model by sizing the two heat exchangers of a standard ORC system. In the study the effect of the backpressure on BSFC of the engine was calculated via a correlation. The study did not investigate the effect of backpressure on exhaust emissions. The studies [13-17] have investigated the negative impact of attaching a waste heat system heat exchanger on the exhaust pipe of diesel engines. Some of the studies have investigated effect of such an appendage on fuel consumption as well. However, these studies have considered the system as a whole with both the engine and waste heat system. Thus, the 
negative impact solely on the engine side could be analyzed incomprehensively.

Few have investigated the effect of backpressure increment on the performance of a diesel engine in detail. Tourlonias and Koltsakis [18] conducted a model-based study to compare the performance of aftertreatment emission reducing systems. In the study the performance indicator was selected as fuel consumption. The results of the study provide fuel penalties from heat-up strategy, filter regeneration and filter loading, and increasing backpressure situations. The study has important results on the effect of different aftertreatment technologies on fuel consumption increment of the engine. However, in the study, the effect of different aftertreatment technologies and backpressure increment on exhaust emissions and performance of the diesel engine has not been investigated. Sapra et al. [19] conducted an experimental investigation of the performance of a marine diesel engine equipped with underwater exhaust system against dynamic back pressure at varying sea-states. A turbocharged marine diesel engine was tested against different backpressures produced by a butterfly valve at the exhaust gas outlet of the turbocharger. The study found that the negative impacts of dynamic backpressure were less influential than static backpressure increment. The study has important implications on the effects of operational dynamics of governor and turbocharger on the fuel penalty due to backpressure increment. However, the study did not investigate the negative impact of backpressure on in-cylinder pressure rise characteristics of the test engine. Sivaram et al. [20] investigated the importance of the exhaust pipe length on fuel economy and volumetric efficiency of a single cylinder diesel engine. The study showed that increased exhaust pipe length and the corresponding increase in the backpressure can lead to increased fuel consumption and decreased volumetric efficiency. In another study [21], marine diesel engine performance against static backpressure was investigated experimentally and via a simulation. In the study, a turbocharged diesel engine was tested under different loads and various static backpressure. Besides, in the study, a simulation model was generated and used to analyze the performance of the engine against high back pressures. Cong et al. [22] studied the effect of backpressure increment on conventional and lowtemperature combustion characteristics of diesel engines. A naturally aspirated single cylinder diesel engine was used as the test engine. The study results showed that increased backpressure does not affected the initial cool flame combustion reactions. However, the backpressure increment caused retarding of the main combustion phase and increased the combustion process. Fernoaga et al. [23] investigated the effect of exhaust backpressure on the power generation characteristics of a diesel engine. In the study, the maximum available shaft power of the engine under different loads and engine speeds was mainly considered as the performance parameter of the engine. The experimental results were used to generate a machine learning algorithm for predicting the maximum available engine power generation under different exhaust backpressures, engine speeds, and engine loads. In another study, [24] a few muffler designs were compared due to backpressure generation characteristics. In the study, computational fluid dynamics software was used to estimate the backpressure increments. Kim and Bae [25] examined the feasibility of replacing the conventional high-pressure loop/low-pressure loop exhaust gas recirculation with a combination of internal and low-pressure loop exhaust gas recirculation system. The aim of such a strategy was to have the availability to retard intake valve closing without the concern of backpressure increment due to the high-pressure loop exhaust gas recirculation. The study has important results for the effect of exhaust backpressure on turbocharger efficiency of the engine. The study mainly focused on the impacts of changing EGR strategy, retarding intake valve closing timing, and negative valve overlap configuration. Thus, the study did not investigate the effect of backpressure on combustion performance, BSFC and exhaust emissions. In another study [26], the characteristics of exhaust gas pressure waves under different engine loads have been investigated. The result showed that the pressure wave in the exhaust line of the engine during the exhaust valves were opened was affected by both the backpressure in the line and in-cylinder pressure. The study results are crucial to understanding the effect of backpressure on the exhaust gas discharge characteristics of a diesel engine. Kasprzyk et al. [27] investigated the effect exhaust backpressure on the operation of exhaust gas oxygen content sensor. The study determined the sensitivity of the sensor to the exhaust pressure under different operational conditions of the test engine. The measurement results of excess air sensor were compared with exhaust gas analysis. Based on the data analysis in the study, a new empirical calculation methodology for the exhaust backpressure compensation correlation for diesel engines was proposed. Andwari et al. [28] investigated the effects of ORC and turbocompound system integration on a diesel engine. In the study, two WHR strategies were modeled and simulated through a 1D simulation by using GT-Power. The strategies were evaluated in terms of their WHR and BSFC reduction capabilities. A rise in the exhaust backpressure increased the fuel consumption so much that the system was unable to regenerate sufficient power to compensate for the power loss in the engine at lower speeds. The study has important 
implications on proving the negative impact of backpressure on engine performance. The study investigated only the negative impacts of backpressure on the BSFC of the engine. However, the backpressure may have many other negative impacts such as increased exhaust emissions, poor composition quality, and deteriorating engine combustion. Michos et al. [29] investigated the effect of an ORC system on the exhaust backpressure of a turbocharged heavy duty marine engine. Ricardo WAVE software was used in the study for the investigation of different turbocharging strategies and the effect of different ORC configurations. The study investigated the effect of backpressure (0-100 mbar) on the engine mass flow rate, BSFC, effective pressure, turbine inlet and compressor pressure, air mass flow rate, and exhaust gas mass flow rate. The study has remarkable results on the effect of exhaust backpressure for engines using different turbocharging strategies. The result showed that the fuel consumption and effective pressure increases, while the air mass flow rate decreases by increasing backpressure for the engine with a fixed turbocharged exhaust system. The results of the study are very critical to understand the effect of backpressure on the performance of an engine with different turbocharging strategies. The study mainly focused on the interaction between engine performance indication parameters, backpressure, and turbocharging strategies [30]. However, the study did not investigate the effects of backpressure on the combustion performance and exhaust emissions. In another study, Lu et al. [31] presented a hypothesis about $\mathrm{NO}_{2}$ formation process in a dual-fuel engine and investigated the effect of methanol proportion in fuel, exhaust gas recirculation, and exhaust backpressure on nitric oxide emissions. The exhaust backpressure was increased by 3, 6, and $9 \mathrm{kPa}$, respectively. In the study, ppm levels of nitric oxide emission were compared for four different backpressure levels and the study determined that $\mathrm{NO}_{\mathrm{x}}$ emissions were increased by increasing backpressure. However, the exhaust backpressure affects the volumetric efficiency of an engine which thus wise would affect exhaust gas mass flow rate. Therefore, the exhaust gas mass flow rate would not be constant for different backpressure levels. Thus, the comparison of $\mathrm{NO}_{x}$ emissions according to ppm levels would not reflect the effect of backpressure on $\mathrm{NO}_{x}$ emissions level. Making the comparison in terms of the brake specific $\mathrm{NO}_{\mathrm{x}}$ emissions levels for various backpressure levels would be more appropriate.

The literature review has shown that any system installed on the exhaust pipe of a diesel engine cause an increase in exhaust backpressure. Increasing backpressure has negative impacts on the performance of an engine. Previous studies on the effects of exhaust backpressure on the performance and exhaust emissions of diesel engines investigated the negative impact of backpressure increment on the BSFC. However, much uncertainty still exists about the relationship between the exhaust backpressure and diesel engine performance indicators such as the volumetric efficiency, mechanical efficiency, combustion characteristics, and environmental impact of diesel engines.

In the current study, the effects of exhaust backpressure increment on the BSFC, volumetric efficiency, mechanical efficiency, brake specific exhaust emissions, and combustion characteristics have been investigated. For this purpose, a single cylinder diesel engine with a dynamometer was used as a test stand, and the exhaust backpressure of the engine was increased by adding different sizes of orifices on the exhaust pipeline of the engine. This study aims to contribute to a deeper understanding of the negative impacts of exhaust backpressure on the efficiency, combustion characteristics, and environmental impact of diesel engines. The results are important to analyze the effect of backpressure increment on the performance of diesel engines, help understand the relationship between exhaust backpressure and in-cylinder pressure, and can be used as a guide to predict the negative impact of installing any type of WHR or aftertreatment system on the exhaust pipe of an engine on the combustion performance. Finally, the study provides suggestions on minimizing the negative impact of backpressure increment.

\section{Materials and Methods}

\subsection{Experimental Setup}

In this study, a test bench was used to analyze the effects of exhaust backpressure on the performance and exhaust emissions of a diesel engine experimentally. Figure 1 illustrates the detailed schematic of the test bench.

As shown in Figure 1, the experimental setup comprises a diesel engine, an electric dynamometer, a fixed orifice housing, a fuel tank, and various measurement devices. The test engine was a single cylinder, direct injection, naturally aspirated, air cooled diesel engine. Table 1 provides the other properties of the test engine. A $20 \mathrm{~kW}$ DC dynamometer was used for loading the engine to any load for any engine speed.

In the experiments, the backpressure was increased by adding orifices of various diameters one by one to the

Table 1. Properties of the test engine

\begin{tabular}{|c|c|}
\hline Items & Specifications \\
\hline Displacement volume - Compression ratio & $817 \mathrm{~cm}^{3}-17: 1$ \\
\hline Bore $\times$ Stroke & $102 \mathrm{~mm} \times 100 \mathrm{~mm}$ \\
\hline Rated Speed & $3000 \mathrm{rpm}$ \\
\hline Maximum Power (kW) (ISO 1585) & $13 \mathrm{~kW} @ 3000 \mathrm{rpm}$ \\
\hline Maximum Torque (Nm) & $48 \mathrm{Nm} @ 1600 \mathrm{rpm}$ \\
\hline
\end{tabular}


housing on the exhaust pipe. The orifices were square edged and concentric bored and made of $2 \mathrm{~mm}$ thick, grade AISI304 stainless steel material. The bore sizes of the orifices in diameter were $28,24,20,16$, and $12 \mathrm{~mm}$, respectively. The diameter of the exhaust pipe without using any orifice was $32 \mathrm{~mm}$.

A Coriolis type flowmeter was used to measure the mass flow rate, temperature, and density of fuel instantaneously. The maximum error rate of the device for mass flow rate measurement was $< \pm 0.1 \%$ for liquids. Similarly, a vortex type flowmeter was used to measure the mass flow rate, temperature, and humidity of intake air. The equipment was connected to the engine suction air inlet via a flexible pipe to avoid equipment damage due to engine vibration and balancing the flow in the measurement device. The maximum error rate of the device for mass flow rate measurement was less than $\pm 2 \%$ for air. The engine load and torque were calculated using the force value measured by a load cell installed on the dynamometer.

The exhaust gas temperature and the rates of $\mathrm{CO}_{2}, \mathrm{O}_{2}$, $\mathrm{CO}, \mathrm{NO}_{\mathrm{x}^{\prime}}$ and $\mathrm{SO}_{\mathrm{x}}$ were measured by an exhaust gas analyzer. The measurement accuracy of the device was in accordance with MARPOL Annex VI and $\mathrm{NO}_{\mathrm{x}}$ Technical Code requirements. Exhaust gas backpressure was measured by using a pressure sensor.

The in-cylinder pressure was measured using a piezoelectric pressure sensor and an appropriate charge amplifier. Additionally, an rpm counter was used simultaneously to measure the engine speed and timing of the top dead center (TDC). TDC timing enabled to determine instantaneous crank angle of the test engine. The in-cylinder pressure and derived crank angle values were used to create open indicator diagrams, which were used to the assess incylinder combustion performance.

\subsection{Experimental Procedure}

The experiments were conducted at an engine speed of $1600 \mathrm{rpm}$, under six different set points of engine torques, and with five different sized orifices. First, the largest sized orifice was attached on the orifice housing. Subsequently, the test engine was run at an engine speed of $1600 \mathrm{rpm}$ under engine torque loads of $8,16,24,32$, and 40 , and 48 $\mathrm{Nm}$. The experimental procedure was repeated by adding orifices of different diameters. The only difference on engine loading procedure with different orifice sizes was the value of maximum engine torque. The maximum producible engine torque was $48 \mathrm{Nm}$ at $1600 \mathrm{rpm}$ engine speed.

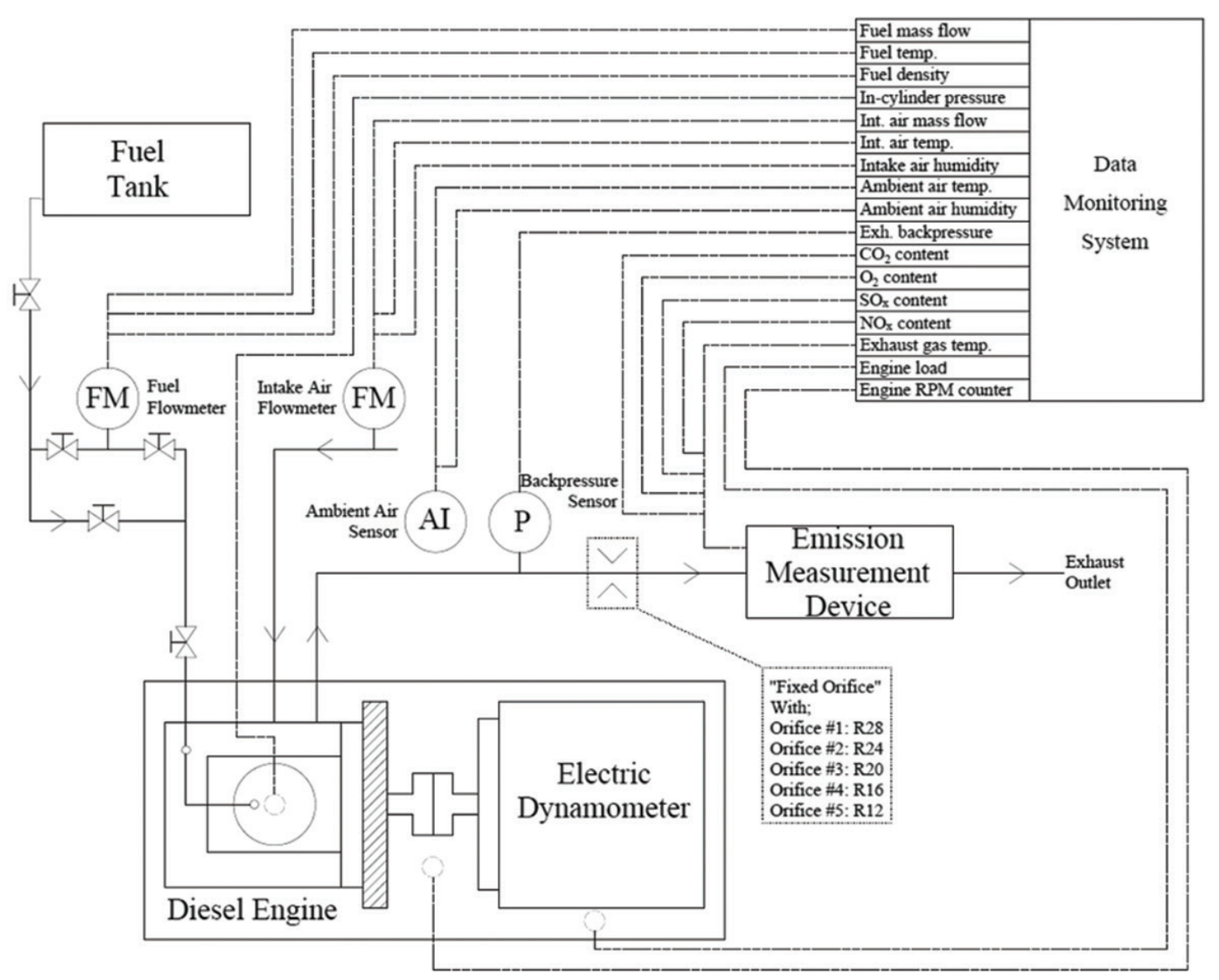

Figure 1. Experimental setup 
However, decreasing the orifice size caused a decrease in the maximum producible engine torque value linearly to 46.43 $\mathrm{Nm}$ with orifice \#5. Thus, the experiments were conducted for the maximum available engine torque in place of $48 \mathrm{Nm}$ with smaller orifices. All the measurement equipment in the test setup were calibrated according to the instruction books, before starting the experiments. It is ensured that all parameters, except for the variables changed for tests, were fixed during the experiments. During the tests, all the measurements were taken $3 \mathrm{~min}$ after the exhaust gas temperature would rise or drop to a constant level.

Fuel flowmeter, intake air flowmeter, ambient air sensor, engine rpm counter, crank angle encoder, load cell, and emission measurement device were "ready to use" measurement devices. Thus, the results of the measurements were converted to a suitable measurement unit by the device itself. For these devices, the measurement results were filtered for noise reduction by device, and the results were read from the device monitor manually for all measurements. Dissimilarly, the in-cylinder pressure sensor and exhaust backpressure measurement sensor have analog outputs and the results of the measurements were collected and converted to a suitable measurement unit by data monitoring system. Additionally, for the two sensors, the noise reduction filtering of measurement results was made by authors using specially designed filters. For this purpose, the output of the in-cylinder pressure sensor with more than 3000 measurement points for each cycle was smoothed using a fifth order Savitsky-Golay filter with a frame length of 73 samples. Data processing for the incylinder pressure measurement was made by four steps. Level correction, angle referencing, cycle averaging and filtering. The signal processing was optimized by a step-bystep offline application methodology in accordance with the methods proposed by Payri et al. [32]. Finally, the noise reduction of the exhaust backpressure sensor was made using a second-order low-pass Butterworth filter with a cut off frequency of $200 \mathrm{~Hz}$.

During the experiments, the test engine was loaded to a specified engine torque at a specified engine speed. Following the appropriate conditions occur, the fuel temperature and mass flow rate, air temperature and mass flow rate, ambient air conditions, volumetric exhaust emission rates and exhaust temperature at measurement point have been read from the monitor of related sensors and recorded. Subsequently, the outputs from exhaust backpressure, crank angle, and in-cylinder pressure sensors were taken, manipulated, and recorded by the data monitoring system. Each measurement was repeated thrice at different times, and the test result value was accepted as the average of the three values. The difference between the average of the three measurements and the end measurement values was found to be $<3 \%$ of the measured value.

\subsection{Calculations}

The test bench enables to measure engine speed, in-cylinder pressure, crank angle, fuel and air properties, exhaust backpressure, exhaust temperature, the force applied to the dynamometer shaft and proportional contents of emissions in the raw exhaust gas. These are measurable parameters. However, the engine torque, brake power, indicated power, any types of the average indicated mean effective pressure (IMEP), BSFC, brake thermal efficiency, volumetric efficiency, mechanical efficiency, and brake specific exhaust emissions cannot be measured directly. These parameters can be derived using one, two, or more of the measured parameters. The engine torque and brake power were derived from the force applied to dynamometer shaft and engine speed. BSFC was calculated by the rate of hourly fuel consumption to energy produced per hour. The net IMEP $\left(\right.$ IMEP $\left._{n}\right)$, gross IMEP (IMEP) and pumping mean effective pressure (PMEP) were calculated by using indicated power values which were gathered by integrating the in-cylinder pressure-volume closed diagram.

Volumetric efficiency $\left(\eta_{v}\right)$ of the engine was calculated by the following formula. In the formula, $m_{\text {air }}^{\prime}$ is the mass flow rate of the intake air, $\rho_{\text {air }}$ is the density of the intake air, $V_{s}$ is the stroke volume, $n$ is the engine speed and $i$ is the number of cycles per one revolution of the engine shaft. Formula 1 is below;

$\eta_{\mathrm{v}}=\frac{\dot{\mathrm{m}}_{\mathrm{air}}}{\rho_{\text {air }} \mathrm{V}_{\mathrm{s}} \mathrm{ni}}$

The brake thermal efficiency $\left(\eta_{b t}\right)$ was calculated using the ratio of the brake power $\left(\rho_{b}\right)$ to the fuel energy. The fuel energy was calculated by multiplying the mass flow rate $\left(m_{\text {fuel }}^{\prime}\right)$ and lower heating value $\left(Q_{L C}\right)$ of the fuel. Formula 2 is below;

$\eta_{\mathrm{bt}}=\frac{\mathrm{P}_{\mathrm{b}}}{\dot{\mathrm{m}}_{\mathrm{fuel}} \mathrm{Q}_{\mathrm{LC}}}$

The mechanical efficiency $\left(\eta_{m}\right)$ was calculated by the ratio of the brake mean effective pressure (BMEP) to IMEP ${ }_{n}$. The BMEP was derived from the brake power and engine displacement volume $\left(V_{d}\right)$. Formula 3 is below;

$\mathrm{BMEP}=\frac{\mathrm{P}_{\mathrm{b}}}{\mathrm{V}_{\mathrm{d}} \mathrm{ni}}$

Finally, brake specific exhaust emissions were derived from volumetric rates of exhaust components in raw exhaust gas 
according to techniques presented in $\mathrm{NO}_{\mathrm{x}}$ Technical Code [33]. For the calculation, the air humidity, density of the exhaust gas (derived from the exhaust temperature and volumetric rates of exhaust components), air flow rate, and fuel flow rate were also used.

\section{Findings and Discussion}

In the study, the effects of backpressure on the performance of a diesel engine were investigated. For this purpose, different sized orifices were added to the exhaust pipe of the engine to increase the backpressure on the exhaust outlet of the engine. Table 2 illustrates the backpressure increment values with different sized orifices under different engine loads. The last column of the table shows the backpressure value with the maximum available torque value. As shown, increasing the engine load has a positive effect on the backpressure values in general. It is probably related with increasing exhaust gas temperature due to increasing engine load. Decreasing orifice radius caused a significant increase in exhaust backpressure.

In the current study, the effects of backpressure increment on the in-cylinder pressure-volume diagrams have been investigated in detail. Figure $2 \mathrm{a}, \mathrm{b}$, c and d illustrate the open and closed in-cylinder pressure diagrams with maximum available engine torque.

As shown in Figure 2c, increasing the backpressure caused a decrease in the peak pressure from 78.36 bar to 70.7 bar. The ignition delay period was increased, the angle of peak pressure was retarded by some $4^{\circ}$ crank angle, and $\mathrm{dp} / \mathrm{d} \theta$ in the rapid pressure rise phase decreased significantly. Details about Figure 2 are provided in Table 3. Cong et al.

Table 2. Measured exhaust backpressure vs engine load and different sized orifice

(Orifices \#1 to \#5 correspond to diameters of 28, 24, 20, 16 and $12 \mathrm{~mm}$, respectively)

\begin{tabular}{|c|c|c|c|c|c|c|}
\hline \multirow{2}{*}{$\begin{array}{l}\text { Orifice no. } \\
\text { load (Nm) }\end{array}$} & \multicolumn{6}{|c|}{ Exhaust backpressure (kPa) } \\
\cline { 2 - 7 } & $\mathbf{8}$ & $\mathbf{1 6}$ & $\mathbf{2 4}$ & $\mathbf{3 2}$ & $\mathbf{4 0}$ & Max. available torque \\
\hline Orifice \#1 & 1.2748 & 1.2748 & 1.2759 & 1.2842 & 1.2852 & $1.2921 \mathrm{at} 48.02 \mathrm{Nm}$ \\
\hline Orifice \#2 & 1.7640 & 1.7582 & 1.7866 & 1.7791 & 1.7800 & $1.799 \mathrm{at} 47.97 \mathrm{Nm}$ \\
\hline Orifice \#3 & 2.9425 & 2.9423 & 2.9706 & 3.0115 & 3.0290 & $3.0853 \mathrm{at} 47.89 \mathrm{Nm}$ \\
\hline Orifice \#4 & 6.9356 & 7.0395 & 7.2912 & 7.3523 & 7.3214 & $7.4822 \mathrm{at} 47.62 \mathrm{Nm}$ \\
\hline Orifice \#5 & 24.1057 & 24.3849 & 25.0422 & 25.3891 & 25.9458 & $26.2589 \mathrm{at} 46.43 \mathrm{Nm}$ \\
\hline
\end{tabular}
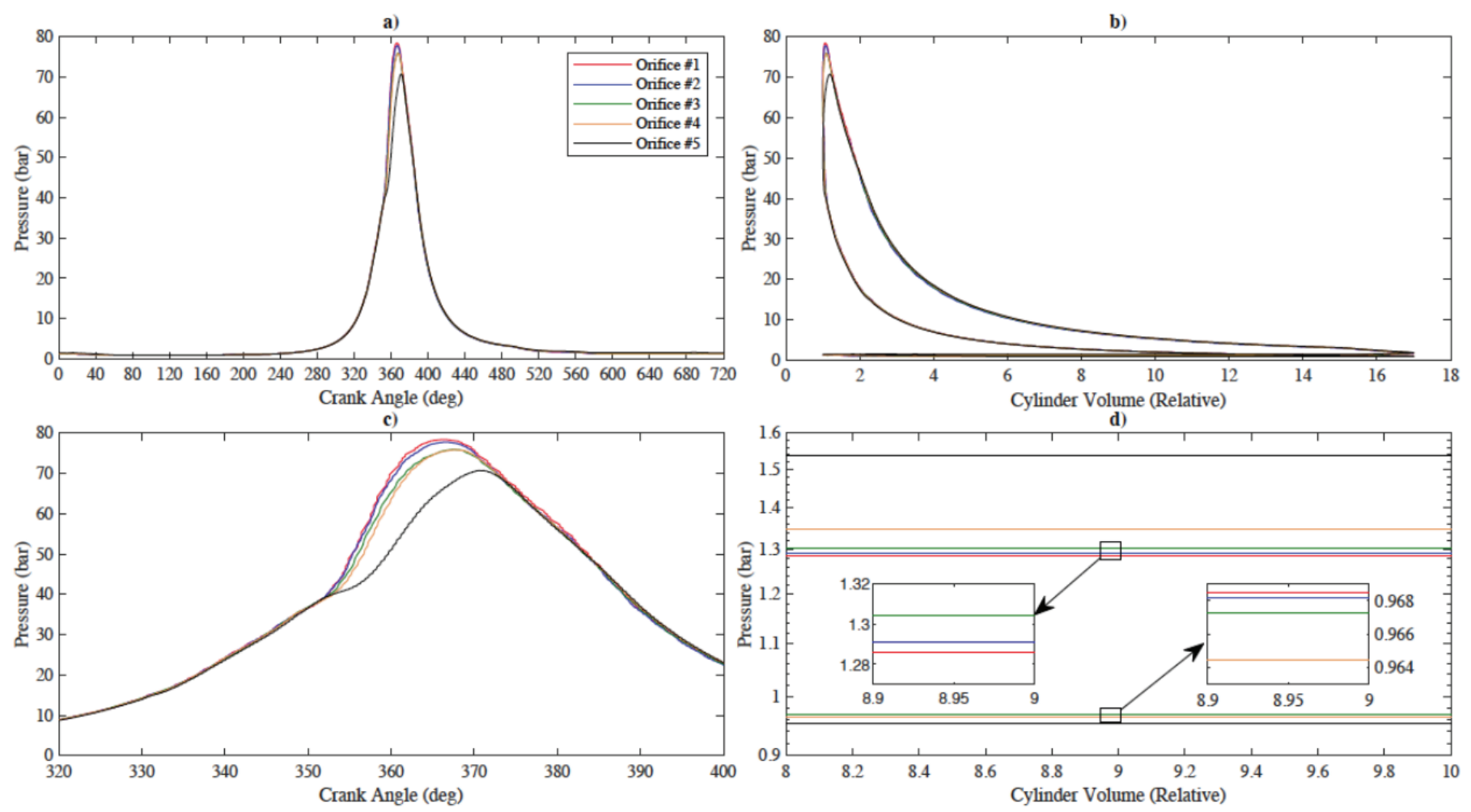

Figure 2. In-cylinder pressure with different orifices under maximum available engine load a) Open indicator diagram, b) Closed indicator diagram, c) Open indicator diagram (detailed view) and d) Intake and exhaust strokes in detail 
[22] investigated in-cylinder pressure for two backpressure scenarios. The results of that study indicated that a higher backpressure caused a retarding of the combustion phases, decrease in combustion duration, and decrease in maximum pressure at $2500 \mathrm{rpm}$ engine speed, $16 \mathrm{mg} /$ cycle fuel consumption, and $30^{\circ}$ crank angle injection advance. The current study showed similar results. However, the previous study investigated the effect of backpressure increment on in-cylinder pressures at constant fuel consumption and thus under different engine loads. The results of the current study enable to understand the impact of backpressure increment on in-cylinder pressures at constant engine load. Clearly, from Table 3, the maximum available engine torques decrease with increasing backpressure. The brake power, net indicated power, and BMEP also decreased. Notably, the PMEP and BSFC values increase with increasing backpressure. In literature, many studies investigated the BSFC increment caused by increasing backpressure. And the results of the current study in accordance with the literature [18-31]. However, no study has investigated the effects of backpressure increment on the mean effective pressure values. There is a small decrease in $\operatorname{IMEP}_{\mathrm{n}}$ and $\mathrm{IMEP}_{\mathrm{g}}$ with increasing backpressure. It may not be a distinct change because these values may decrease when decreasing the engine torque. However, the increment in PMEP values may be good sign to observe the negative impact of backpressure increase. As seen from the table, PMEP values increase with decreasing orifice radius significantly. Conceivably, this is directly related to the resistance against exhaust gas flow due to higher pressure in the exhaust pipe. An increase in PMEP decreased exhaust gas discharge efficiency in exhaust stroke and relatedly decreased the volumetric efficiency. In the literature, Hield [34] has investigated PMEP increase effect of exhaust backpressure increment in diesel engines. However, according the result of that study, backpressure increment caused a slight increase in PMEP values once compared with the results of the current study. This may be due to the test engine in the study was a turbocharged engine, and thus, the PMEP increase effect of backpressure increment may has been absorbed by turbocharger.

In Figure 2 and Table 3, the maximum available torque values decrease with decreasing orifice radius. This may cause a comparison of the effect of backpressure on performance parameters such as indicated mean effective pressure values under non-equivalent conditions. To make an assessment under equal circumstances, engine torque values were equalized to some $40 \mathrm{Nm}$ value. Figure $3 \mathrm{a}, \mathrm{b}$, $c$ and $d$ show open and closed indicator diagrams under 40 $\mathrm{Nm}$ engine torque, $1600 \mathrm{rpm}$ engine speed and with five different sized orifices.

In Figure 3, the effects of backpressure increment on the in-cylinder pressure rise characteristics are similar to those shown in Figure 2. However, the only difference is that, Figure 3 enables to make a comparison on the effect of backpressure increment on BSFC, IMEP, PMEP, and friction mean effective pressure (FMEP) under equal engine torque levels. Details about Figure 3 are provided in Table 4.

Table 4 shows the results obtained from the analysis of the pressure-volume diagram shown in Figure 3. Data from this table can be compared with the data listed in Table 3. Decreasing the engine torque caused a decrease in the brake power and mean effective pressure values. However, the BSFC values slightly increase. Once the effect of increasing backpressure on the performance parameters is compared under same engine torque conditions, it can be clearly seen that increased backpressure causes a slight decrease

Table 3. Performance parameters at maximum available engine torque

\begin{tabular}{|c|c|c|c|c|c|}
\hline Orifice \# & 1 & 2 & 3 & 4 & 5 \\
\hline Engine speed (rpm) & 1604 & 1602 & 1601 & 1591 & 1593 \\
\hline Torque $(\mathrm{Nm})$ & 48.02 & 47.97 & 47.89 & 47.62 & 46.43 \\
\hline Brake power $(\mathrm{kW})$ & 8.07 & 8.05 & 8.03 & 7.94 & 7.75 \\
\hline Net indicated power $(\mathrm{kW})$ & 9.09 & 9.06 & 9.05 & 8.91 & 8.68 \\
\hline IMEP $_{n}$ & 8.32 & 8.31 & 8.30 & 8.22 & 8.00 \\
\hline $\mathrm{IMEP}_{\mathrm{g}}$ & 8.64 & 8.63 & 8.63 & 8.63 & 8.52 \\
\hline PMEP & 0.32 & 0.32 & 0.33 & 0.40 & 0.52 \\
\hline FMEP & 0.26 & 0.26 & 0.27 & 0.29 & 0.26 \\
\hline BMEP & 7.39 & 7.38 & 7.37 & 7.33 & 7.14 \\
\hline BSFC (g/kW.h) & 255.92 & 255.84 & 257.23 & 259.08 & 265.78 \\
\hline Crank angle at maximum pressure (deg) & 366.6 & 366.6 & 367.4 & 367.7 & 370.6 \\
\hline Maximum pressure (bar) & 78.36 & 77.75 & 75.92 & 75.82 & 70.70 \\
\hline
\end{tabular}


in $\operatorname{IMEP}_{n}$ under all orifice sizes. Because $\operatorname{IMEP}_{n}$ is equal to the difference between IMEP ${ }_{\mathrm{g}}$ and PMEP, increase in PMEP causes a decrease the IMEP ${ }_{n}$ values. Once the change in BSFC values is investigated, it can be assumed that increasing backpressure increases BSFC of the engine. Considering the backpressure values in Table 2 and BSFC values in Table 4, it can be deduced that a backpressure increase of $0.49 \mathrm{kPa}$ caused an increase of $0.34 \%$ in $\mathrm{BSFC}, 6.04 \mathrm{kPa}$ backpressure increase caused an increase of $1.05 \%$ in BSFC, and $24.66 \mathrm{kPa}$ backpressure increase caused an increase of 3.29\% in BSFC. Interestingly, from Table 3, IMEP ${ }_{\mathrm{g}}$ values vary with increasing backpressure. IMEP $_{\mathrm{g}}$ values decrease with increasing backpressure value up to $3.029 \mathrm{kPA}$ with orifice\#3. However, increasing the backpressure from $3.029 \mathrm{kPa}$ to $7.3214 \mathrm{kPa}$ caused an increase in IMEP $_{\mathrm{g}}$ value. Thereafter, the increasing trend continues with increasing

Table 4. Performance parameters at $40 \mathrm{Nm}$ engine torque

\begin{tabular}{|c|c|c|c|c|c|}
\hline Orifice \# & 1 & 2 & 3 & 4 & 5 \\
\hline Engine speed (rpm) & 1602 & 1593 & 1600 & 1592 & 1605 \\
\hline Torque $(\mathrm{Nm})$ & 40.42 & 40.27 & 40.29 & 40.32 & 40.25 \\
\hline Brake power $(\mathrm{kW})$ & 6.78 & 6.72 & 6.75 & 6.72 & 6.76 \\
\hline Net indicated power $(\mathrm{kW})$ & 7.80 & 7.71 & 7.74 & 7.69 & 7.71 \\
\hline $\operatorname{IMEP}_{\mathrm{n}}$ & 7.15 & 7.11 & 7.10 & 7.09 & 7.05 \\
\hline IMEP $_{g}$ & 7.43 & 7.40 & 7.39 & 7.45 & 7.54 \\
\hline PMEP & 0.28 & 0.29 & 0.29 & 0.36 & 0.48 \\
\hline FMEP & 0.37 & 0.39 & 0.35 & 0.37 & 0.29 \\
\hline BMEP & 6.22 & 6.19 & 6.20 & 6.20 & 6.19 \\
\hline BSFC (g/kW.h) & 259.10 & 259.97 & 259.95 & 261.83 & 267.64 \\
\hline Crank angle at maximum pressure (deg) & 365.5 & 365.7 & 367.2 & 367.5 & 370.1 \\
\hline Maximum pressure (bar) & 74.72 & 75.00 & 73.39 & 72.62 & 69.02 \\
\hline
\end{tabular}
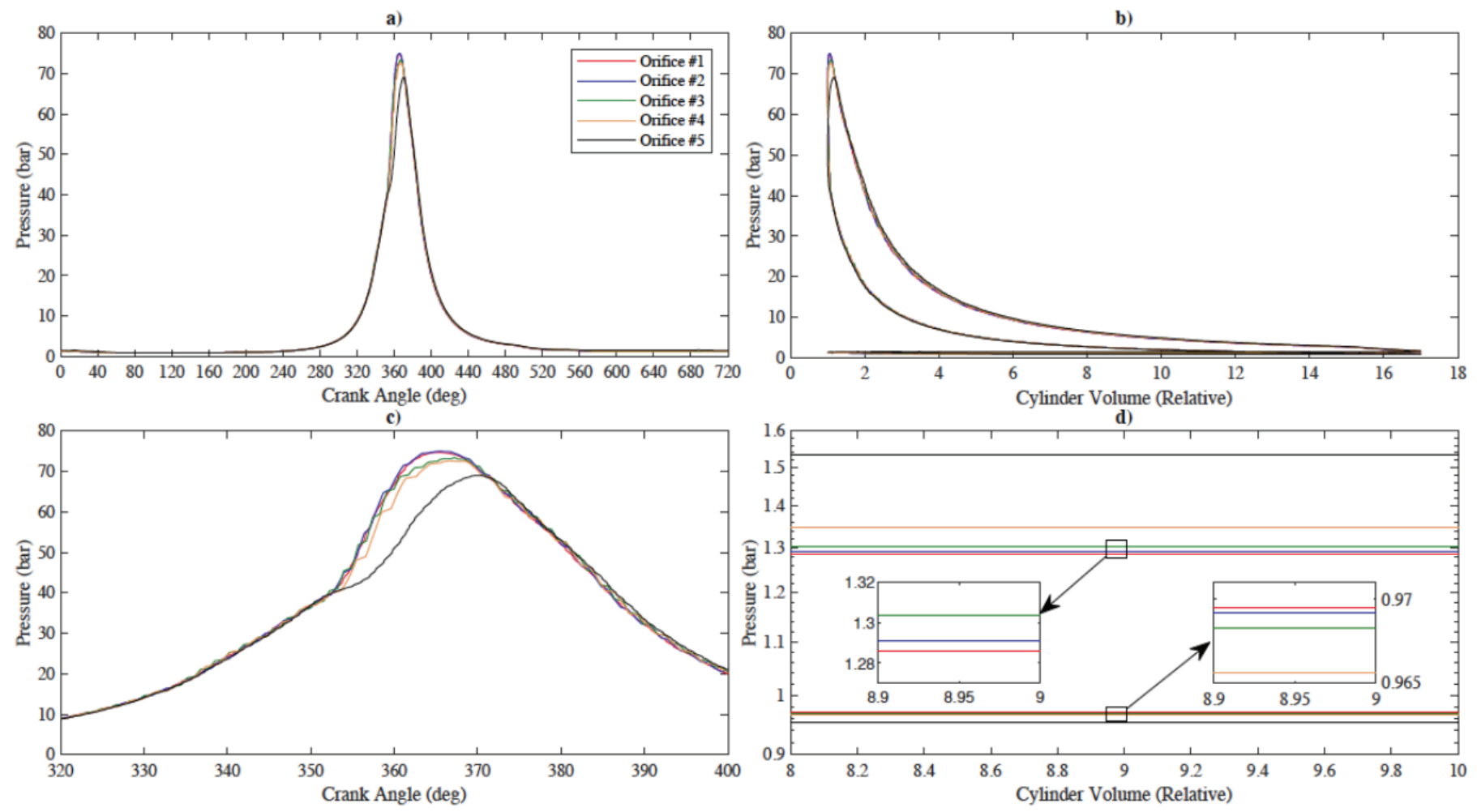

Figure 3. In-cylinder pressure with different orifices at an engine load of $40 \mathrm{Nm}$ : a) Open indicator diagram, b) Closed indicator diagram, c) Open indicator diagram (zoomed in view) and d) Intake and exhaust strokes in detail 
backpressure after that. As shown, $\operatorname{IMEP}_{\mathrm{n}}$ data increase steady, however IMEPg data fluctuate. The difference may be caused due to the gas exchange process. Moreover, the fluctuations in the mechanical efficiency originate from the change in the volumetric efficiency.

IMEP $_{n}$, IMEP $_{g^{\prime}}$ PMEP and FMEP values are affected by increasing backpressure under $40 \mathrm{Nm}$ engine torque as illustrated in Table 4. Decreasing the engine torque to lower values also has similar trends in mean effective pressure values. Figure $4 a, b, c$ and $d$ show the changes in mean effective pressure values with increasing backpressure under different engine loads.

Figure 4 shows the effect of different engine torques and increasing backpressure on the mean effective pressure values of test engine at an engine speed of $1600 \mathrm{rpm}$. As shown in Figure 4a, b and d, the changing trends are similar to the trends under an engine torque of $40 \mathrm{Nm}$. Decreasing the engine load caused a decrease in IMEP $_{n}$ and IMEP $_{g}$ due to the decrease in power production. In PMEP values, there is also a similar trend in the plot. As Figure 4d investigated, it can be stated that at all engine loads, $25.1 \mathrm{kPa}$ backpressure increment with orifice \#5 caused some 50\% PMEP increase while $7.3 \mathrm{kPa}$ increment with orifice \#4 and 3.2 $\mathrm{kPa}$ backpressure increment with orifice \#3 caused $28.6 \%$ and 3.2\% PMEP increments respectively. In the literature,
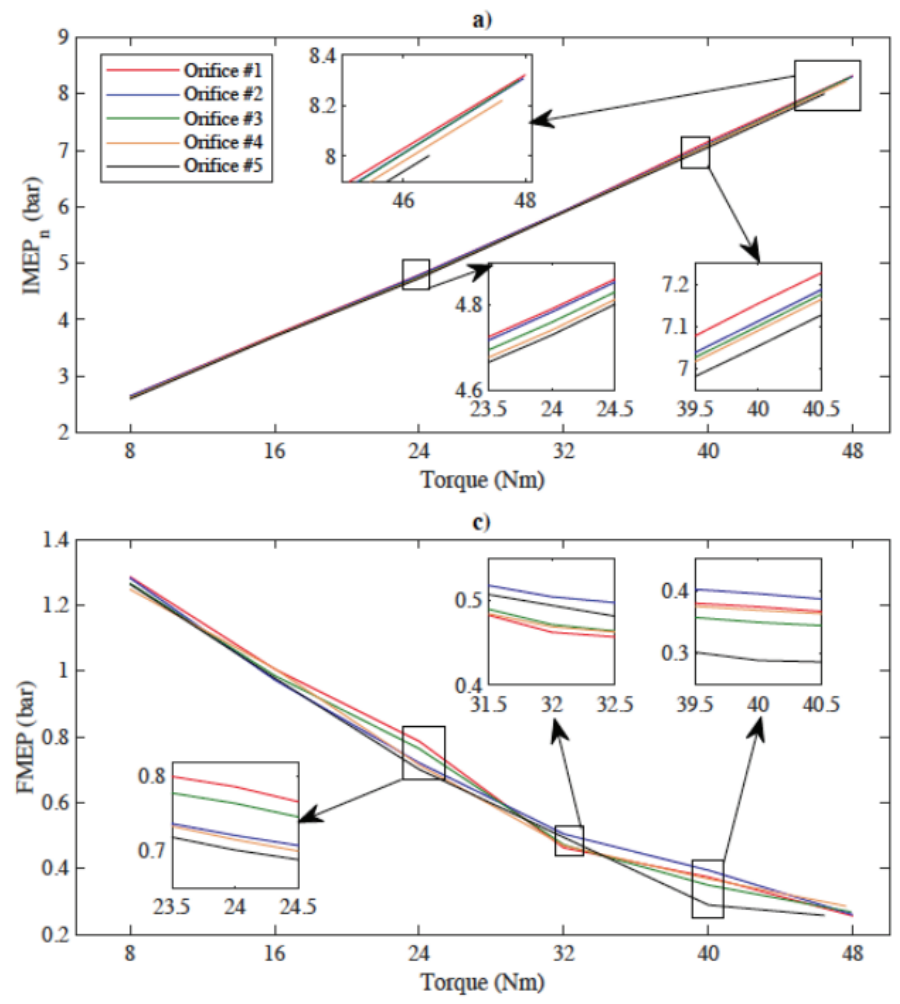

Michos et al. [29] measured some 15\% PMEP increase at 10 $\mathrm{kPa}$ backpressure using a fixed turbocharged diesel engine. The variation may be caused by the difference between test engines. In that study, a turbocharged diesel engine was used as the test engine, and a fixed turbocharger may lead to absorption of a part of the negative impact of backpressure increment on the pumping work of the engine.

Mean effective pressure values are critical indicators of the fuel economy and efficiency of the test engine. However, there are other performance indicators such as mechanical efficiency $\left(\eta_{m}\right)$, brake thermal efficiency $\left(\eta_{b t}\right)$, volumetric efficiency $\left(\eta_{v}\right)$, and BSFC. Figure 5a, b, c and d illustrate the effect of increasing backpressure and changing engine load on engine performance parameters.

Figure 5 shows that increasing the backpressure causes a significant increase in the BSFC. BSFC increased averagely $3.2 \%$ at approximately $25.1 \mathrm{kPa}$ backpressure, $\% 1.2$ at approximately $7.2 \mathrm{kPa}$ backpressure and $\% 0.4$ at approximately $3 \mathrm{kPa}$ backpressure. In the literature, many studies $[11,16,18,29,31]$ investigated BSFC penalty of backpressure increment. The results of the current study are similar to results of that studies. For instance, Zhang et al. [11] has found that BSFC increased $4.57 \%$ at $25.1 \mathrm{kPa}$ backpressure, while an increment was observed as $0.73 \%$ at $7.8 \mathrm{kPa}$ and $0.44 \%$ at $4.5 \mathrm{kPa}$ backpressure. In another

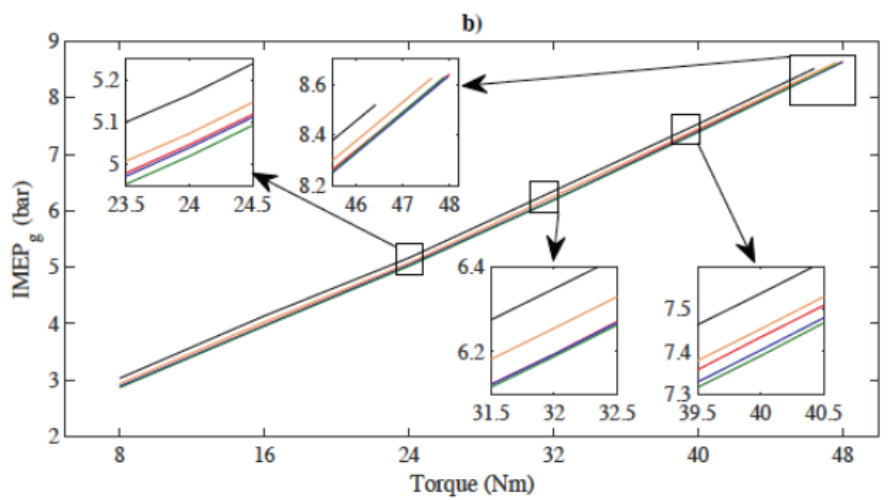

d)

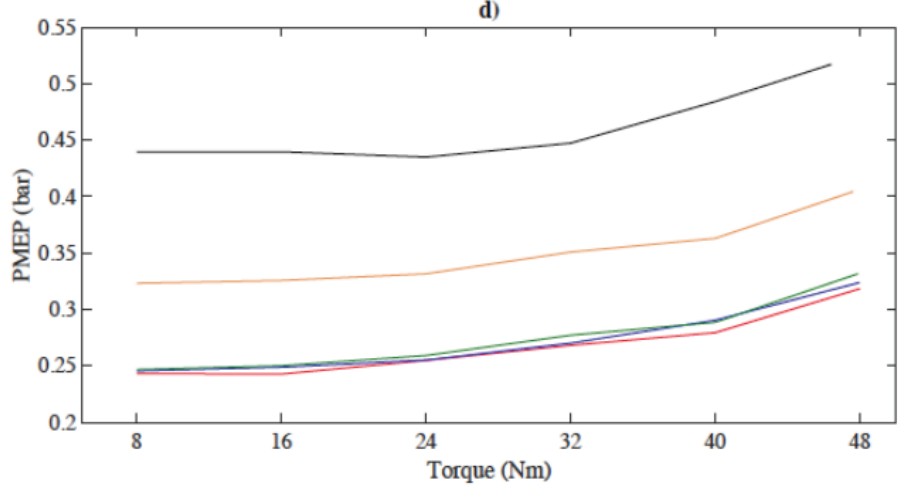

Figure 4. Mean effective pressure values a) IMEP ${ }_{n^{\prime}}$ b) $I M E P_{g^{\prime}}$ c) FMEP and d) PMEP

$I M E P_{n}:$ Net indicated mean effective pressure, IMEP ${ }_{g}$ :Gross indicated mean effective pressure, PMEP: Pumping mean effective pressure, FMEP: Friction mean effective pressure 
study, Karvountzis-Kontakiotis et al. [16] have stated that BSFC increased $2 \%$ with $25 \mathrm{kPa}$ and $0.5 \%$ with $10 \mathrm{kPa}$ backpressure increment. However, no published study has attempted to investigate the mechanism between backpressure increment and BSFC increase. As shown in Figure 2 and Figure 3, the backpressure increment caused retarding of the combustion phases. As the backpressure increases, the angle of ignition start and the angle of maximum pressure were retarded significantly. Besides, $\mathrm{dp} / \mathrm{d} \theta$ on rapid pressure rise phase has decreased. In the literature, many studies which investigated the effects of fuel injection timing on combustion of diesel engines [35-38] have found that advancing fuel injection timing caused retarding of combustion phases and a decrease in $\mathrm{dp} / \mathrm{d} \theta$ on rapid pressure rise phase as similar to negative impacts of increasing backpressure. Thus, when running the engine against high exhaust backpressure, retarding the injection timing may result in an abatement in the fuel penalty. This may be a new research topic for researchers.

One of the most apparent impact of backpressure increment on the performance parameters of a diesel engine is the impact on the volumetric efficiency, as shown in Figure $5 \mathrm{~b}$. As shown in the figure, changing load also affected the volumetric efficiency. For instance, with orifice\#4, volumetric efficiency was increased from $82.97 \%$ at 8

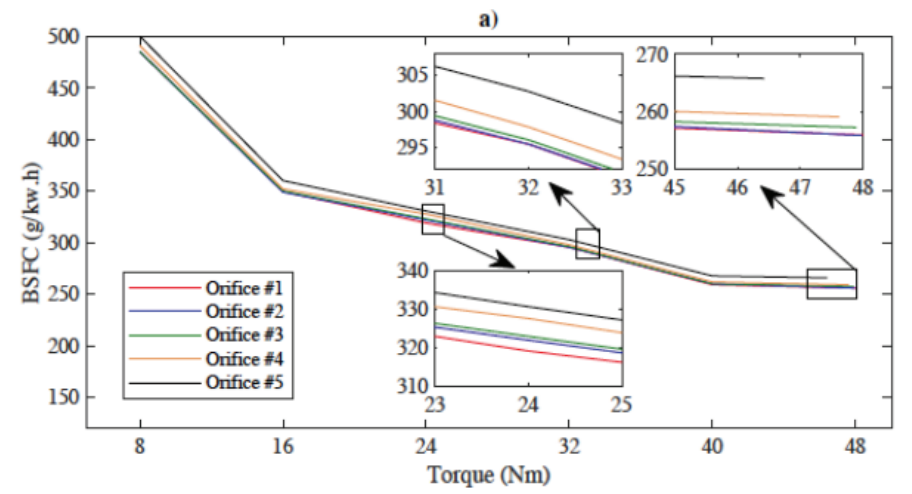

c)

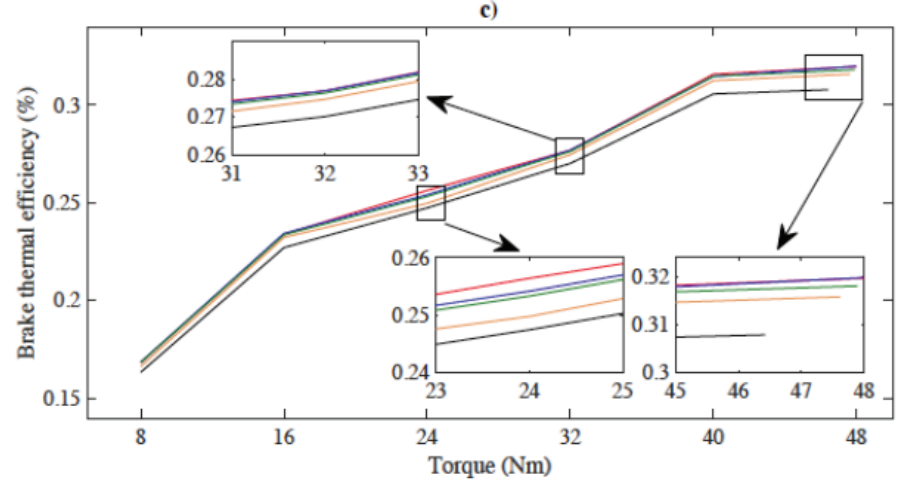

$\mathrm{Nm}$ torque to $84.68 \%$ at maximum engine load. However, increasing backpressure clearly decreased the volumetric efficiency of the engine. For example, at an engine load of $40 \mathrm{Nm}$, the volumetric efficiency decreased from $86.56 \%$ with orifice\#1 to $83.39 \%$ with orifice\#5. This was probably due to the increased pumping work required for the test engine. In exhaust stroke, exhaust gas discharging efficiency was decreased due to backpressure increment. Increasing the quantity of the remained gas in the cylinder caused a decrease in the intake air quantity aspirated in the intake stroke. As illustrated in Figure $5 \mathrm{c}$, the brake thermal efficiency is directly related with BSFC, and decreasing the BSFC causes an increase in the brake thermal efficiency and vice versa.

In Figure $5 \mathrm{~d}$, the effect of backpressure increment on mechanical efficiency of test engine was illustrated. As seen, backpressure increment has a slight positive effect on mechanical efficiency. For instance, at $40 \mathrm{Nm}$ engine load, the mechanical efficiency increased from $86.98 \%$ with orifice\#1 to $87.51 \%$ with orifice\#5. This may be a secondary result of decreased maximum in-cylinder pressure and IMEP due to backpressure increment.

Figure $6 \mathrm{a}, \mathrm{b}, \mathrm{c}$ and $\mathrm{d}$ illustrate the effect of backpressure increment on $\mathrm{CO}$ and $\mathrm{NO}_{\mathrm{x}}$ emissions. Figure $6 \mathrm{a}$ and $6 \mathrm{~b}$ shows the emissions in volumetric ratio. Figure $6 \mathrm{c}$ and $6 \mathrm{~d}$ shows the emissions as brake specific exhaust emissions.

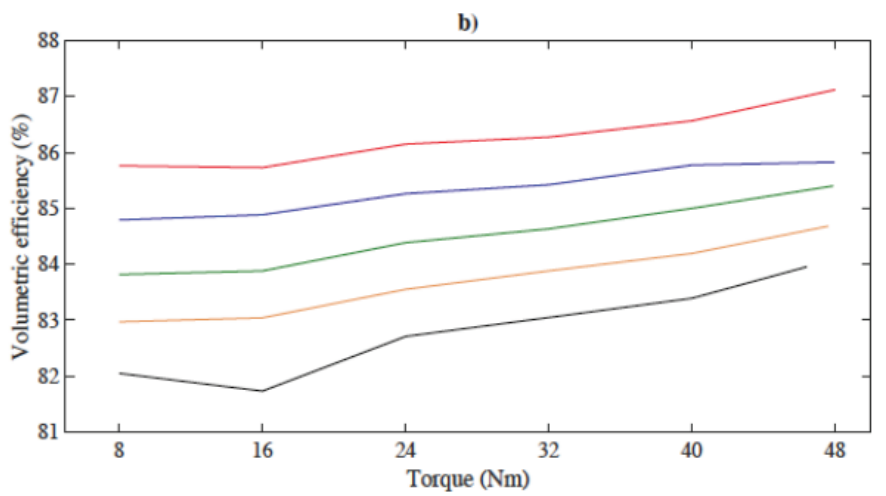

d)

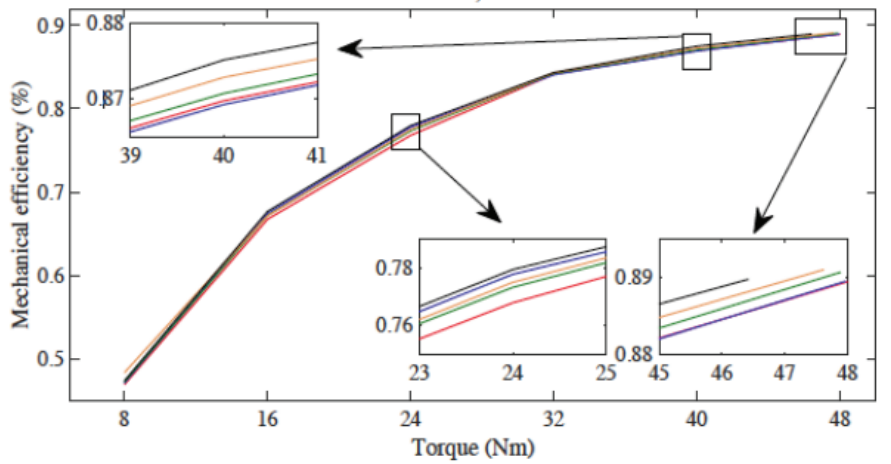

Figure 5. Efficiency values under different loads a) BSFC, b) $\eta_{v}$ c) $\eta_{b t}$ and $\eta_{m}$ BSFC: Brake specific fuel consumption 
As shown in Figure 6a and 6-c, which presents increasing backpressure up to $3 \mathrm{kPa}$ with orifice\#3, there is no significant change under any loading. Increasing backpressure from approximately 1.28 to $1.78 \mathrm{kPa}$ has caused a slight decrease in brake specific $\mathrm{CO}$ emissions as shown in Figure 6c. For example, at an engine torque of $40 \mathrm{Nm}$, brake specific CO emissions decreased from 5.1565 to $5.1405 \mathrm{~g} / \mathrm{kW}$.h. From another view, increasing the backpressure to approximately $3 \mathrm{kPa}$ has also resulted a decrease from 5.1565 to 5.0692 g/kW.h in brake specific CO emissions. Dissimilarly, increasing the backpressure to $7.2 \mathrm{kPa}$ and $25.1 \mathrm{kPa}$ with orifice \#4 and orifice \#5, respectively, caused a significant increase in brake specific $\mathrm{CO}$ emissions. At $40 \mathrm{Nm}$ engine load, the brake specific $\mathrm{CO}$ emissions increased to 5.85 and $6.38 \mathrm{~g} / \mathrm{kW}$.h respectively. It is almost similar for volumetric CO emissions. On the other hand, increasing backpressure also caused a decrease in $\mathrm{NO}_{\mathrm{x}}$ emissions as shown in Figure $6 \mathrm{~d}$. At an engine torque of $40 \mathrm{Nm}$, brake specific $\mathrm{NO}_{\mathrm{x}}$ emissions decreased from $10.17 \mathrm{~g} / \mathrm{kW} . \mathrm{h}$ to $9.99,10.01,9.6$, and $9.32 \mathrm{~g} / \mathrm{kW}$.h values with decreasing orifice size. The reason behind the decreasing trend is probably related to the decreasing in-cylinder pressure with increasing backpressure, as shown in Figure 2 and Figure 3. According to Zeldovich [39] Mechanism and Fenimore [40] Mechanism the generation of nitric oxides is directly related with incylinder pressure and in-cylinder temperatures. Thus, increasing the backpressure causes decrease of in-cylinder
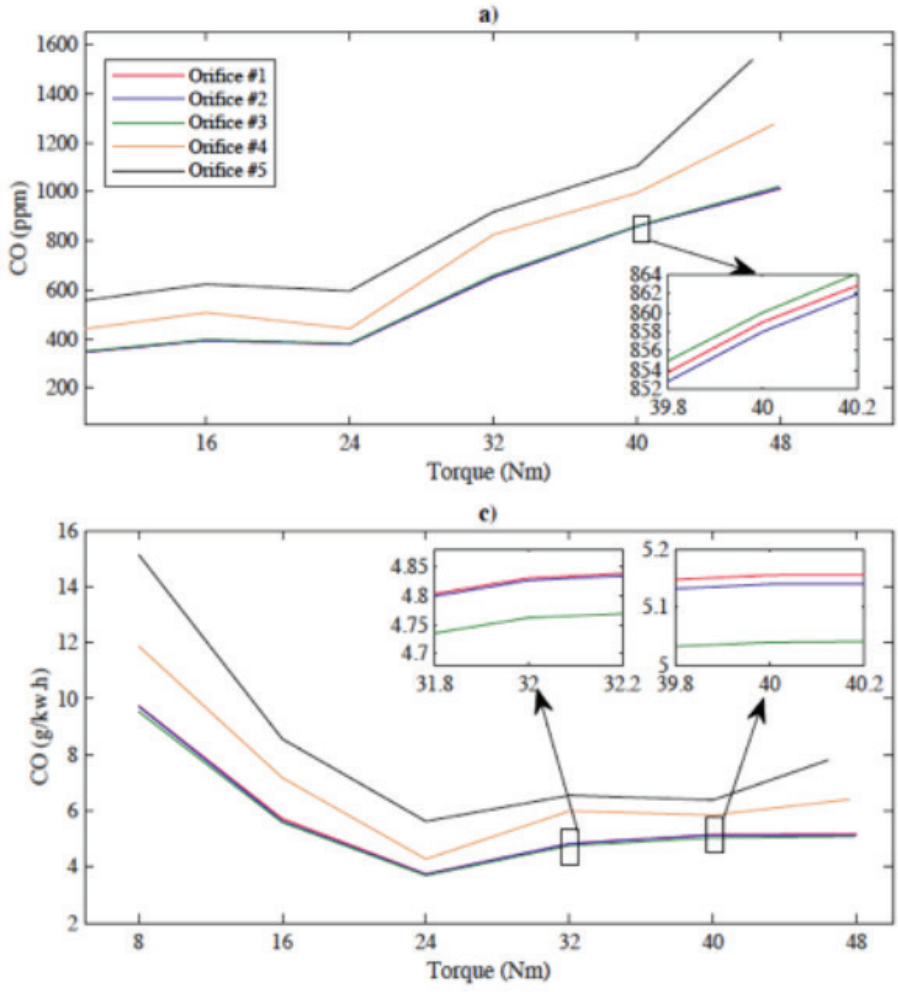

pressure and temperatures and thus it results a significant decrease in brake specific $\mathrm{NO}_{\mathrm{x}}$ emissions.

\section{Conclusion}

The current study was designed to determine the effect of backpressure increment on the performance parameters of a diesel engine. In the experimental study, the exhaust backpressure was increased by installing different sized orifices on the exhaust pipe.

The impacts of backpressure increment on in-cylinder pressure characteristics, mechanical efficiency, brake thermal efficiency, BSFC, volumetric efficiency, and exhaust emissions of the engine were analyzed. From the experimental results, the following conclusions can be drawn:

Increasing exhaust backpressure caused increase in time (as crank angle) for ignition delay. This can be attributed to the retarding of the combustion phases such as rapid pressure rise and main combustion. In addition, the angle of peak pressure was retarded, and the peak cylinder pressure decreased.

The BSFC of the engine increased with backpressure increment. The BSFC increasing characteristics obtained in the current study is similar to the results in previous studies. However, no published study has attempted to find the relationship between BSFC increment and in-cylinder pressure characteristics. In the current study, it was
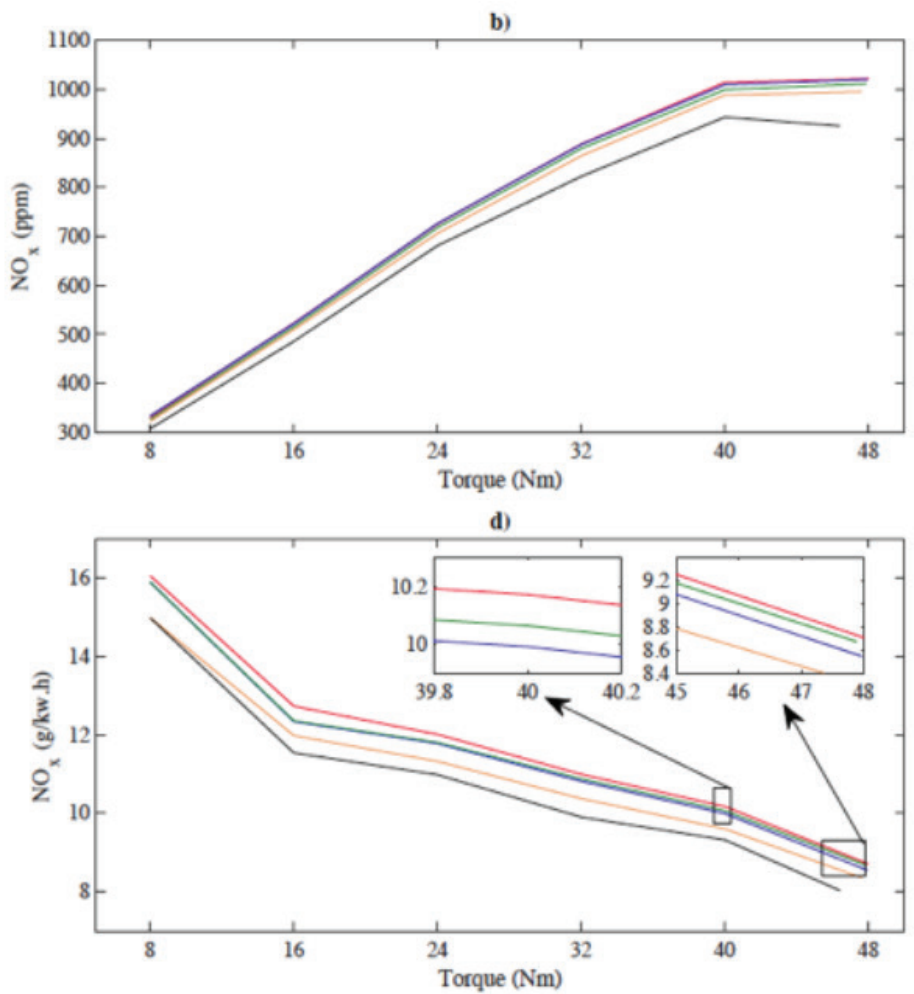

Figure 6. Exhaust emissions under different loads and backpressures: a) CO (ppm), b) $\left.\left.N O_{x}(p p m) c\right) C O(g / k W \cdot h), d\right) N O_{x}(g / k W . h)$ 
found that the combustion phases were retarded because of the backpressure increment. Given that retarding the combustion phases causes an increase in BSFC, as a suggestion, some part of BSFC increment penalty may be possibly abated by advancing the fuel injection timing and thus advancing combustion phases. The question raised by the current study may be a new research goal for further studies.

IMEP $_{n}$ values was decreased with backpressure increment. The main reason behind such a reduction was the increasing trend in the PMEP values, which significantly increased with increasing backpressure. This was an expected outcome due to the strong correlation between the difference in the exhaust and intake manifold pressures and the pumping losses.

The volumetric efficiency of the test engine decreased with increasing backpressure. As the volumetric efficiency is the measure of breathing ability of an engine, probably the increasing flue gas quantity remained in-cylinder after exhaust stroke caused such a reduction. The mechanical efficiency of the engine increased with increasing backpressure. The main reason behind this positive result may be the negative impact of decreasing the force applied to piston and bearings.

The backpressure increment caused an increase in CO emissions especially with higher backpressure. However, a small increment in the backpressure caused a slight decrease in $\mathrm{CO}$ emissions. On the other hand, the emissions of nitric oxides (in ppm) decreased with increasing backpressure.

The backpressure increment caused a decrease in the maximum available torque values. Thus, the engine torque decreased to $46.4 \mathrm{Nm}$ from $48 \mathrm{Nm}$ under high backpressure.

The current study has some limitations, e.g., the generalizability of the results. For instance, the effects of backpressure increment for the current test engine was studied in detail and the results of the study is repeatable for the specific test engine. However, no experimental study was conducted using different engine models or under different operational conditions. Notwithstanding these limitations, the study suggests that the backpressure increment causes a decrease in almost all performance indicators of diesel engines. The findings will be useful for studies to be conducted on estimating the level of negative impact of installing any system on exhaust pipe of an engine such as aftertreatment or WHR systems. Further researches can be conducted to optimize the engine operational parameters to minimize the negative impact of backpressure increment on engine performance. The study can be reproduced in a different engine testing laboratory with a different test engine to make generally accepted evaluation about the role of backpressure increment on the performance of diesel engines.

\section{Authorship Contributions}

Concept design: Y. Gülmez, G. Özmen, Data Collection or Processing: Y. Gülmez, Analysis or Interpretation: Y. Gülmez, G. Özmen, Literature Review: Y. Gülmez, Writing, Reviewing and Editing: Y. Gülmez, G. Özmen.

Funding: The authors declared that this study received no financial support.

\section{References}

[1] M. Naseri, C. Aydin, S. Mulla, R. Conway and S. Chatterjee, "Development of emission control systems to enable high $\mathrm{NO}_{\mathrm{x}}$ conversion on heavy duty diesel engines," SAE International Journal of Engines, vol. 8, pp. 1144-11451, Apr 2015.

[2] C. Zhang, C. Sun, M. Wu, and K. Lu, "Optimisation design of SCR mixer for improving deposit performance at low temperatures," Fuel, vol. 237, pp. 465-474, Feb 2019.

[3] A.J. Martyr and M.A. Plint, "Engine exhaust emissions," in Engine Testing (Fourth Edition), A.J. Martyr and M.A. Plint, Eds. Oxford: Butterworth-Heinemann, 2012, pp.407-450. [Online]. Available: Science Direct, https://doi.org/10.1016/B978-0-08-0969497.00016-9. [Accessed: May 5, 2021].

[4] A. M. Stamatellou and A. Stamatelos, "Overview of diesel particulate filter systems sizing approaches," Applied Thermal Engineering, vol. 121, pp. 537-546, Jul 2017.

[5] Z. Li, K. Jue, D. Lou, X. Zhong, and Y. Zhang, "Effect of electric diesel particulate trap on particulate emission characteristics of lightduty diesel engine," IOP Conference Series Earth Environmental Science, vol. 510, 2020.

[6] I. Rounce, M. Bogarra, J. M. Herreros, F. J. Martos Ramos, and A. Tsolakis, "Understanding the effects of catalytic partial flow filters on particle removal efficiency," Results in Engineering, vol. 4, Sep 2019.

[7] F. D’Aniello, B. Rossomando, I. Arsie, and C. Pianese, "Development and experimental validation of a control oriented model of a catalytic DPF," SAE Technical Paper 2019-01-0985. pp. 1-14, Apr 2018.

[8] J. He, K. Chen and J. Xu, "Urban air pollution and control," in Encyclopedia of Sustainable Technologies, M.A. Abraham, Eds. Cambridge: Elsevier, 2017, pp. 243-257.

[9] O. Chiavola, G. Chiatti, and N. Sirhan, "Impact of particulate size during deep loading on DPF management," Applied Sciences, vol. 9, 2019.

[10] Y. Cui, et al. "Combustion and emission characteristics of wood pyrolysis oil-butanol blended fuels in a DI diesel engine," International Journal of Automotive Technology, vol. 19, no. 5, pp. 759-769, 2018, [Online]. Available: Springer Link, https://doi. org/10.1007/s12239. [Accessed: May 5, 2021].

[11] J. Zhang, V. W. Wong, S. Shuai, Y. Chen and A. Sappok, "Quantitative estimation of the impact of ash accumulation on diesel particulate filter related fuel penalty for a typical modern on-road heavy- duty diesel engine" Applied Energy, vol. 229, pp. 1010-1023, Nov 2018. 
[12] H. Wang, et al. "The effects of ash inside a platinum-based catalyst diesel particulate filter on particle emissions, gaseous emissions, and unregulated emissions," Environmental Science and Pollution Research, vol. 25, pp. 33736-33744, Oct 2018.

[13] X. Wu, J. Chen, and L. Xie, “Optimal design of organic Rankine cycles for exhaust heat recovery from light-duty vehicles in view of various exhaust gas conditions and negative aspects of mobile vehicles," Applied Thermal Engineering, vol. 179, Oct 2020.

[14] E. Baldasso, M. E. Mondejar, J. G. Andreasen, K. A. T. Rønnenfelt, B. Ø. Nielsen, and F. Haglind, "Design of organic Rankine cycle power systems for maritime applications accounting for engine backpressure effects," Applied Thermal Engineering, vol. 178, pp. 115527, Sep 2020.

[15] M. Zhao, M. Wei, P. Song, Z. Liu, and Z. Wang, "Effects of the ORC operating conditions on the engine performance for an engineORC combined system," Energy Procedia, vol. 105, pp. 662-667, May 2017.

[16] A. Karvountzis-Kontakiotis, I.Pesmazoglou, and L. Tocci, "Effect of an ORC waste heat recovery system on diesel engine fuel economy for off-highway vehicles," SAE Technical Paper 2017-01-0136, [Online]. Available: SAE Mobilus, https://doi. org/10.4271/2017-01-0136. [Accessed: May 5, 2021].

[17] D. Di Battista, M. Di Bartolomeo, C. Villante, and R. Cipollone, "A model approach to the sizing of an ORC unit for WHR in transportation sector," SAE International Journal of Commercial Vehicles, vol. 10, pp. 608-617, Apr 2017.

[18] P. Tourlonias and G. Koltsakis, "Model-based comparative study of Euro 6 diesel aftertreatment concepts, focusing on fuel consumption," International Journal of Engine Research, vol. 12, pp. 238-251, June 2011.

[19] H.D. Sapra, J. Singh, C. Dijksta, P. de Vos and K. Visser, "Experimental investigations of marine diesel engine performance against dynamic back pressure at varying sea-states due to underwater exhaust systems," in ASME 2019 Internal Combustion Engine Division Fall Technical Conference, ICEF 2019, 20 October 2019 - 23 October 2019, [Online]. Available: https://asmedigitalcollection.asme.org/ICEF/ICEF2019/ volume/59346, [Accessed: June 6, 2021].

[20] A. R. Sivaram, R. Rajavel, N. Jayakumar and M. Vinothkumar "Exhaust back pressure effect on the performance features of a diesel engine," ARPN Journal of Engineering and Applied Sciences, vol. 12, pp. 5353-5356, Oct 2017.

[21] H. D. Sapra, M. Godjevac, K. Visser, D. Stapersma and C. Dijksta, "Experimental and simulation-based investigations of marine diesel engine performance against static back pressure" Applied Energy, vol. 204, pp. 78-92, Oct 2017.

[22] S. Cong, G.P. McTaggart-Cowan and C. P. Garner, "The effects of exhaust back pressure on conventional and low temperature diesel combustion" in IMechE's Internal Combustion Engines: Performance, Fuel Economy and Emissions Conference, London, 8December 2009-9 December 2009, [Online]. Available: https:// journals.sagepub.com/doi/10.1177/09544070JAUT01577, [Accessed: June 6, 2021].

[23] V. Fernoaga, V. Sandu and T. Balan, "Artificial intelligence for the prediction of exhaust back pressure effect on the performance of diesel engines," Applied Sciences, vol. 10, pp. 7370, Sep 2020.
[24] S. Thirumurugaveerakumar, "Design and optimization of muffler back pressure" in International Conference on Physics and Chemistry of Materials in Novel Engineering Applications AIP Conf. Proc. 2270, 120001-1-120001-7, 2020, [Online]. Available: https://doi.org/10.1063/5.0019700, [Accessed: June $6,2021]$.

[25] J. Kim and C. Bae, "Emission reduction through internal and low-pressure loop exhaust gas recirculation configuration with negative valve overlap and late intake valve closing strategy in a compression ignition engine," International Journal of Engine Research, vol. 18, pp. 973-990, Feb 2017.

[26] Z. Yang, S. et al. "Preliminary investigation of exhaust pressure waves in a single cylinder diesel engine and the impacts on aftertreatment sprays," SAE International Journal of Engines, vol. 10, pp. 636-645, April 2017.

[27] P. Kasprzyk, J. Hunicz, A. Rybak, M. S. Geca and M. Mikulski, "Excess air ratio management in a diesel engine with exhaust backpressure compensation" Sensors, vol. 20, pp. 1-16, Nov 2020.

[28] A. M. Andwari, A. Pesyridis, V. Esfahanian, A. Salavati-Zadeh, and A. Hajialimohammadi, "Modelling and evaluation of waste heat recovery systems in the case of a heavy-duty diesel engine," Energies, vol. 12, pp. 1397, Apr 2019.

[29] C. N. Michos, S. Lion, I. Vlaskos, and R. Taccani, "Analysis of the backpressure effect of an Organic Rankine Cycle (ORC) evaporator on the exhaust line of a turbocharged heavy duty diesel power generator for marine applications," Energy Conversion Management, vol. 132, pp. 347-360, Jan 2017.

[30] Y. Choi, A. Negash, and T. Y. Kim, "Waste heat recovery of diesel engine using porous medium-assisted thermoelectric generator equipped with customized thermoelectric modules," Energy Conversion and Management, vol. 197, pp. 111902, Oct 2019.

[31] H. Lu, A. Yao, C. Yao, C. Chen, and B. Wang, "An investigation on the characteristics of and influence factors for NO2 formation in diesel/methanol dual fuel engine," Fuel, vol. 235, pp. 617-626, Jan 2019.

[32] F. Payri, J.M. Luja'n, J. Martı́n and, A. Abbad, "Digital signal processing of in-cylinder pressure for combustion diagnosis of internal combustion engines," Mechanical Systems and Signal Processing, vol. 24, pp. 1767-1784, Aug 2010.

[33] International Maritime Organization Marine Environment Protection Committee, "Resolution MEPC.177(58) NOx Technical Code," 2008, [Online]. Available: https://wwwcdn.imo.org/ localresources/en/KnowledgeCentre/IndexofIMOResolutions/ MEPCDocuments/MEPC.177(58).pdf. [Accessed: May. 5, 2021].

[34] P. Hield, "The effect of backpressure on the operation of diesel engines," MA: Australia Government, Department of Defence, Maritime Platform Division, 2011. [Online]. Available: https:// apps.dtic.mil/sti/pdfs/ADA542137.pdf. [Accessed: May. 5, 2021].

[35] E. F. Pehlivan and İ. Altın, "Biyodizel pilot püskürtmeli doğalgaz yakıtıyla çalışan bir dizel motorda silindir basıncı değişiminin stokastik reaktör model kullanılarak incelenmesi," Journal of Eta Maritime Science, vol. 5, pp. 5-17, 2017.

[36] A.K. Agarwal, et al, "Effect of fuel injection pressure and injection timing of Karanja biodiesel blends on fuel spray, engine performance, emissions and combustion characteristics," 
Energy Conversion and Management, vol. 91, pp. 302-314, Feb 2015.

[37] A. Yousefi, H. Guo and M. Birouk, "Effect of diesel injection timing on the combustion of natural gas/diesel dual-fuel engine at lowhigh load and low-high speed conditions," Fuel, vol. 235, pp. 838846, 2019.

[38] K. Bayramoğlu and M. Nuran, "Analyzing the effect of fuel injection timing and injection duration on performance and emissions in diesel engines" Journal of Eta Maritime Science, vol. 8, pp. 38-52, 2020.
[39] Y.B. Zeldovich, "The oxidation of nitrogen in combustion and explosions" in Selected Works of Yakov Borisovich Zeldovich, Volume I Chemical Physics and Hydrodynamics, G. I. Barenblatt and Rashid Alievich Sunyaev, Eds. Oxford: Princeton University Press, 1992, pp. 364-403.

[40] C. P. Fenimore, "Formation of nitric oxide in premixed hydrocarbon flames," Symposium (International) on Combustion, vol. 13, pp. 373-380, 1971. 